\title{
FRAMING THEORETICAL CONTRIBUTIONS: THE AC/DC POSITIONING GRID
}

\author{
Matej Černe \\ University of Ljubljana
}

How to frame theoretical contributions in a way that positions them within existing literature-specific conversations in a meaningful way is a challenge that has bedeviled researchers for decades. Theory is at the very heart of scholarship, and is a key criterion for evaluating the quality and contribution of research (Cornelissen, Höllerer \& Seidl, 2021). Theory is an "umbrella concept" (Suddaby, 2014) or a "container term" (Sandberg \& Alvesson, 2021). It refers to the scholarly work that researchers do in pursuit of making informed claims about a generalizable account of events in the social world. As Cornelissen et al. (2021, p. 3) put it,

The informed nature of these claims refers here to the fact that researchers make a qualified assertion regarding how something can generally be understood or explained, or indeed how they argue it should be compared to familiar or more limited understandings. The strength of researchers' claims rests directly on the scholarly work that they have done, and how this has been articulated in a paper; for example, in sharply defining concepts or constructs, in developing a coherent set of explanations, or by offering a compelling point of critique that counters past thinking on a topic.

To no surprise, review and editorial comments regarding "overaching theory," "theoretical contributions," or "the so-what question" are almost everpresent in contemporary review processes in academic journals, often acting as gates between submitted research reports and their actual publication. Implications for theory and relevance of a particular piece for the extant literature are extremely important issues underlying the fact that new research actually provides something unique beyond the current body of knowledge. Many prominent researchers and their contributions thus have addressed challenges related to theorizing and making theoretical contributions in recent decades (e.g., Whetten, 1989; DiMaggio, 1995; Sutton \& Staw, 1995; Weick, 1995; Feldman, 2004; Cornelissen \& Durand, 2014). At the same time, review comments listed above as examples oftentimes come across as generic and vague, without clear and constructive guidance about how the submitted manuscripts could be improved upon regarding those matters.

Providing an accurate account of (1) what the extant literature already knows ("standing on the shoulders of giants"), (2) what currently is missing (what are the gaps/lacunas in the existing research), (3) what new research will do and in what way, and (4) how it contributes to the existing conversations are key elements that scholars usually include in the front (introduction) part of their papers. The components described above also can act as a template ("the four-paragraph model"1) for crafting an introduction, for example, by devoting a paragraph to each of the points above. Such an approach can help scholars navigate the most important elements of their positioning. The "craft" side of scholarly writing also embodies a well-documented area of academic endeavor, producing many important and readily applicable guidelines published in the form of articles, books and book chapters, or editorials (e.g., Bem, 1987; Bergh, 2003; Fernandez, 2020; Grant \& Pollock, 2011; Gregor \& Hevner, 2013). In recent years, many of those resources have moved online, producing outlets such as institutional (university) or other research writing guides, and online coaches and materials.

1 The author thanks the anonymous reviewer of one of the earlier submissions of author's work to one of the top journals in the field of management. That manuscript was rejected at the time, but this constructive comment resulted in many subsequent papers hopefully being framed much better. 
Despite these foundations and resources, how to actually approach positioning research within existing conversations, and how to evaluate, describe, narrate, and articulate particular contributions to the "existing table occupied by already published research(ers) on the topic," remains an open, creative, imaginative task. At the same time, it epitomizes an intangible, difficult, elusive undertaking, often leaving scholars without ideas about how to tackle it successfully. This editorial complements existing pieces referred to above by offering and describing a tool that can help scholars do this, framing their thought process and assisting in providing an accurate account of specific contributions.

The framework described and depicted in Table 1 encompasses two sets of elements. The rows include four ways a particular contribution can be framed; it can Advance (progress), Complement (integrate), Debunk (contrast), or Confirm (corroborate) existing conversations in the literature, constituting the AC/DC positioning grid/matrix. This editorial describes and provides examples of each of those types of positioning, additionally describing them through elements provided in the column headers of the grid.

I argue that each contribution should be positioned specifically in a way that defines the scholarly field (broad research area - narrower field specific topic) in which it attempts to make a contribution, to which discussion in the extant literature it intends to contribute, the key authors and their contributions to the conversation, the scope of this potential contribution, and why it is relevant theoretically (not just logically or practically). These all represent evaluation criteria for specific contributions, which can take one of four key types of framing a theoretical contribution.
(1) Advancing or progressing a particular scholarly discussion implies that the new contribution would alter, fundamentally or marginally, an existing theoretical point of view of a specific topic. Such a contribution would imply that the scholarly conversation would be steered in a different (not opposing, just modified) direction on the basis of presented findings. The conversation would be advanced by the presented evidence that will need to be accounted for in ongoing discussion (i.e., contributions succeeding it). For example,

We intend to advance the literature of consumer negativity towards brands by highlighting the mechanism of the occurrence of obsessive behaviours. We propose that obsess is more likely to occur when consumers hate the brand. (Japutra, Roy, \& Pham, 2021, p. 2)

Such a theoretical contribution progresses the literature in such a way that subsequent studies in the marketing field on the topic of consumer negativity will have to consider consumer hate as a mechanism of obsessive behavior.

2) Complementing an existing conversation implies that the research adds something to the current body of knowledge, simply complementing what we already know with additional insight. This insight could stem from a different (empirical) context that has theoretical implications, it could stem from a different theoretical background (for example, with a different theoretical perspective providing additional insight into the studied matter dominated by another theoretical framework), or it could be achieved through integration of conceptualizations and findings from different areas of research. For instance,

Table 1. The $A C / D C$ positioning grid for framing theoretical contributions

\begin{tabular}{|l|l|l|l|l|l|}
\hline $\begin{array}{l}\text { How does the } \\
\text { contribution ... }\end{array}$ & $\begin{array}{c}\text { Which } \\
\text { field? }\end{array}$ & $\begin{array}{c}\text { Which } \\
\text { discussion? }\end{array}$ & $\begin{array}{c}\text { By which } \\
\text { authors? }\end{array}$ & $\begin{array}{c}\text { Scope of the contribution } \\
\text { (small, moderate, large) }\end{array}$ & $\begin{array}{c}\text { Why is it relevant? } \\
\text { (theoretically, not just practically) }\end{array}$ \\
\hline Advance/progress & & & & & \\
\hline Complement/integrate & & & & & \\
\hline Debunk/contrast & & & & & \\
\hline Confirm/corroborate & & & & & \\
\hline
\end{tabular}


We intend to complement the literature on budgeting in institutional complexity, and the funding situation matters in a study that deals with budgeting. (Amans, Mazars-Chapelon, \& Villesèque-Dubus, 2015, p. 52)

Such a contribution would imply that the study of the topic of budgeting in institutional complexity thus far has not considered the funding situation, and that this paper complements the current stream of research with this perspective.

(3) Debunking or contrasting existing research implies that the current perspective or viewpoint prevalent in the existing conversation does not hold, either universally, or in a specific setting. In claiming such a type of theoretical contribution, authors frequently provide contrasting evidence that enables additional theoretical development for contrasting the current stream of research. Insights used to develop such counter views could stem from a different theoretical perspective that the current body of knowledge has not yet considered, or a recombination of theoretical viewpoints that have been used to date. For example,

The big myth the authors aim to debunk is that creativity cannot really be managed-that it's a largely solitary process involving a few somewhat eccentric individuals with very high IQs. (Holt, 1999, p. 15)

Here, the author provides strong evidence that counters the existing "myth" in the creativity literature. With such a contribution, one is bound to contrast existing streams and individuals, which perhaps raises fears of such a contribution not being accepted well. However, science is updating and renewing constantly, and most academic should be glad to see their ideas or findings that might have worked in a particular context, or were appropriate in light of particular zeitgeist, challenged with novel evidence or different streams of thought.

(4) Finally, and just the opposite of \#3, confirming or corroborating existing research also is a noble feat, especially in light of the reproducibility and replicability crisis in social sciences. Although frequently interpreted as perhaps less "grand" and radical of a contribution, it nonetheless is crucially needed, either as a form of generalization (i.e., confirming a finding in a different context or replicating in similar contexts) or as a stepping stone for another contribution that can advance or complement what has been confirmed additionally. For example,

In a dynamic perspective, we have argued that SMEs are therefore more responsive to intensifying disincentives for innovation than large firms are. We intend to corroborate this view by controlling for confounding factors such as those resulting from changes in sector compositions or growth dynamics of particularly innovative firms. (Rammer \& Schubert, 2018, p. 384)

The authors attempt to confirm and verify the assertion previously posited in the literature by adding additional controls. These shed additional light onto findings, and make conclusions more rigorous in light of including controls of sector compositions or firms' growth dynamics. In this way, such a contribution does not shift or change the viewpoint present in a particular area of research, but makes it more robust and generalizable.

Taken together, the AC/DC framework is a grid or a matrix, meaning that not all cells need to be (and almost surely will not be) filled by positioning one academic paper. As a rule of thumb, there usually are one to three, or likely a maximum of as many as five key contributions each paper makes. Each of them could very well be placed in the same positioning type (e.g., they all could complement existing streams, but perhaps different streams), and definitely not all positioning types need to be covered. The tool and its underlying table is intended to be adapted to a specific paper that attempts to make specific contributions, depending on the content.

Next I demonstrate the application of the $A C / D C$ positioning matrix on our published piece in Human Resource Development Quarterly (Hernaus, Černe, \& Škerlavaj, 2021). In this paper, we drew on a relational perspective to human resource development and management (HRD/M), and conducted a multilevel and multisource field study that examined how HRM practices of job interaction requirements/task interdependence and HRD practice of cross-training interact to enhance employees' job/task citizenship performance. We presented three contributions to the literature at the intersection of $\mathrm{HRD} / \mathrm{M}$. 
First, we complemented existing HRD/M research that has traditionally focused on narrowly defined employees' job/task performance by validating the importance of social job characteristics (i.e., communication and coordination) for a specific type of extra-role performance. Second, we advanced the conversation linking training interventions with job design decisions to achieve workplace performance targets, something that was mentioned in the late 1980s and early 1990s (we used the expression "we reopen the discussion") by accounting for both organizational- and individuallevel constructs, providing evidence that organizations need to put an additional team training effort to develop lateral capabilities of their workforce in addition to socially enriched job design. Third, we contrasted the traditional view of HRD that has considered it to be a subspecialization of HRM, offering a showcasing example of how a multilevel perspective on HRD can create transdisciplinary value. Table 2 summarizes how these contributions were framed.
To conclude, the tool described in this editorial perhaps could be applied universally. However, it was developed on the basis of prior research stemming from the business, management, organization studies, and organizational behavior/psychology fields, likely making it more suitable in those areas. The examples mentioned herein reflect the author's background, knowledge of the fields, and search history. The list is not exhaustive, and even better examples likely exist.

It needs to be emphasized that the use of this tool is preconditioned by deep analysis of the existing literature, careful thought related to conceptualizing research, and executing it in an honest way in the best form possible. The AC/DC matrix with its elements is intentionally simplistic, and is intended to assist prospective academic writers and make their job easier, enabling them to focus on the actual content of their contributions. However, the craft of clever writing and positioning a paper in a more articulate manner cannot replace the much-needed excellence in all the other parts of the research journey.

Table 2. The application of the positioning grid in Hernaus et al. (2021)

\begin{tabular}{|c|c|c|c|c|c|}
\hline $\begin{array}{l}\text { How does the } \\
\text { contribution ... }\end{array}$ & Which field? & Which discussion? & By which authors? & $\begin{array}{l}\text { Scope of the } \\
\text { contribution (small, } \\
\text { moderate, large) }\end{array}$ & $\begin{array}{l}\text { Why is it relevant? } \\
\text { (theoretically, not just } \\
\text { practically) }\end{array}$ \\
\hline Advance & $\mathrm{HRD} / \mathrm{M}$ & $\begin{array}{l}\text { Linking training } \\
\text { interventions with job } \\
\text { design decisions to } \\
\text { achieve performance } \\
\text { targets. }\end{array}$ & $\begin{array}{l}\text { Campbell et al., } \\
\text { 1993; Felstead et } \\
\text { al., 2009; Marsick } \\
\text { \& Watkins, 2015; } \\
\text { McLagan, } 1989\end{array}$ & Moderate & $\begin{array}{l}\text { Accounting for constructs at } \\
\text { different levels; the } \\
\text { importance of developing } \\
\text { lateral capabilities of their } \\
\text { workforce in addition to } \\
\text { socially enriched job design. }\end{array}$ \\
\hline Complement & $\mathrm{HRD} / \mathrm{M}$ & $\begin{array}{l}\text { Narrowly defined } \\
\text { job/task performance; } \\
\text { importance of social job } \\
\text { characteristics and } \\
\text { extra-role performance. }\end{array}$ & $\begin{array}{l}\text { Alagaraja, 2013; } \\
\text { Mohan \& Sophia, } \\
\text { 2019; Wong et al., } \\
2017\end{array}$ & Moderate & $\begin{array}{l}\text { New cross-disciplinary HRM- } \\
\text { HRD nexus knowledge about } \\
\text { socially structured and } \\
\text { cognitive aspects of human } \\
\text { behavior. }\end{array}$ \\
\hline $\begin{array}{l}\text { Debunk/ } \\
\text { contrast }\end{array}$ & $\mathrm{HRD} / \mathrm{M}$ & $\begin{array}{l}\text { Depart from a } \\
\text { traditional } \\
\text { subspecialized role of } \\
\text { HRD and acknowledge } \\
\text { that HRD has become a } \\
\text { well-established and } \\
\text { mature field of its own. }\end{array}$ & $\begin{array}{l}\text { Jeung et al., 2011; } \\
\text { McLagan, 1989; } \\
\text { Ruona, 2016; } \\
\text { SHRM, 2014; } \\
\text { Torraco, 2005a; } \\
\text { Yoo et al., } 2019\end{array}$ & Moderate & $\begin{array}{l}\text { Demonstrating how a } \\
\text { multilevel perspective on HRD } \\
\text { can create transdisciplinary } \\
\text { value. }\end{array}$ \\
\hline
\end{tabular}

Note: References listed in the table are presented in Hernaus et al. (2021) 
The basic idea of making academic writing even more of a "craft" does not come without challenges. Undoubtedly, it makes academic papers, especially those reporting similar types of research designs, more and more similar to one another. This notion acts counter the concept of intellectual pluralism upon which academia is (or should be) founded. To some extent, this does diminish creativity that is left to researchers in crafting their manuscripts. At the same time, excellent research always should come through, regardless of its format, and many journals have become open to accepting manuscripts that employ innovative techniques of writing, research design, or indeed structuring specific elements of final research reports. The current academic system of publishing might not be optimal, but it is the best we have. Members of the academic community should strive to uphold it in an ethical way, doing our best to approach it with utmost care, responsibility, and diligence. We all take part in, compose, and contribute to the academic world. Let us act in making it a place that celebrates excellent research that is articulated in the best manner possible.

\section{REFERENCES}

Alvesson, M., \& Sandberg, J. (2011). Generating research questions through problematization. Academy of Management Review, 36(2), 247-271.

Amans, P., Mazars-Chapelon, A., \& Villesèque-Dubus, F. (2015). Budgeting in institutional complexity: The case of performing arts organizations. Management Accounting Research, 27, 47-66.

Bem, D. (1987). Writing the empirical journal article. The complete academic: A practical guide for the beginning social scientist, 2, 185-219.

Bergh, D. D. (2003). From the Editors: Thinking Strategically about Contribution. Academy of Management Journal, 46(2), 135-136.

Cornelissen, J. P., \& Durand, R. (2014). Moving forward: Developing theoretical contributions in management studies. Journal of Management Studies, 51(6), 9951022.

Cornelissen, J., Höllerer, M. A., \& Seidl, D. (2021). What Theory Is and Can Be: Forms of Theorizing in Organizational Scholarship. Organization Theory, 2(3), 1-19.

DiMaggio, P. J. (1995). Comments on "What theory is not". Administrative science quarterly, 40(3), 391-397.

Feldman, D. C. (2004). What are We Talking About When We Talk About Theory? Journal of Management, 5(30), 565-567.
Fernandez, K. V. (2020). PROVE it! A practical primer to positioning theoretically. Australasian Marketing Journal, 28(1), 57-64.

Grant, A. M., \& Pollock, T. G. (2011). Publishing in AMJPart 3: Setting the Hook. Academy of Management Journal, 54(5), 873-879.

Gregor, S., \& Hevner, A. R. (2013). Positioning and presenting design science research for maximum impact. MIS Quarterly, 337-355.

Hernaus, T., Černe, M., \& Škerlavaj, M. (2021). The interplay between relational job design and cross-training in predicting employee job/task citizenship performance. Human Resource Development Quarterly, DOI: $10.1002 / \mathrm{hrdq} .21427$.

Japutra, A., Roy, S. K., \& Pham, T. A. N. (2021). Relating brand anxiety, brand hatred and obsess: Moderating role of age and brand affection. Journal of Retailing and Consumer Services, 60, 102465.

Sandberg, J., \& Alvesson, M. (2021). Meanings of theory: Clarifying theory through typification. Journal of Management Studies, 58, 487-516

Suddaby, R. (2014). Why theory? Academy of Management Review, 39, 407-411

Sutton, R. I., \& Staw, B. M. (1995). What theory is not. Administrative Science Quarterly, 371-384.

Whetten, D. A. (1989). What Constitutes a Theoretical Contribution? Academy of Management Review, 14(4): 490-495.

Weick, K. E. (1995). What Theory Is Not, Theorizing Is. Administrative Science Quarterly, 40(3): 385-390. 